Robinson, G. L. (1951). J. gen. Microbiol. 5, 788-792.

\title{
The Haemolysin of Bacterium coli
}

\author{
BY G. L. ROBINSON
}

Seamen's Hospital, Greenwich

SUMMARY: Conditions for haemolysis by Bacterium coli have been investigated. The haemolytic factor is specific to haemolytic strains only, has not at present been separated from living bacterial cells, is associated with the logarithmic phase of growth, and requires for its action the presence of calcium ions.

Except for an article by Dudgeon, Wordley \& Bawtree (1921) suggesting a connexion between haemolytic and pathogenic effects, unconfirmed in ensuing years, the subject of haemolysis by Bacterium coli appears to have received little attention since the report by Kayser (1903) of a heat-resistant filterable haemolysin, particularly active upon dog red cells, which was produced during the later, more alkaline, phase of growth in an acid broth. A repetition of some of Kayser's experiments led me to the conclusion that his haemolysin was simply carbonate; and a re-examination of the haemolytic action of Bact. coli was undertaken, using chemically-defined media for growth.

\section{METHODS}

Ten strains of Bact. coli (seven haemolytic, three non-haemolytic for mammalian red cells, man, dog, horse, ox, sheep) two strains of Aerobacter aerogenes (non-haemolytic) and one Intermediate strain (non-haemolytic) were used in this work, all being from human sources (urinary infections or faeces) except the last, which was isolated from cow's milk. Cultivation at $37^{\circ}$ was carried out in a defined minimal medium (Robinson, 1932) consisting of: sodium acetate $\left(\mathrm{NaC}_{2} \mathrm{H}_{3} \mathrm{O}_{2} \cdot 3 \mathrm{H}_{2} \mathrm{O}\right), \mathbf{2} \cdot 5$ g.; sodium citrate $\left(\mathrm{Na}_{3} \mathrm{C}_{6} \mathrm{H}_{5} \mathrm{O}_{7} \cdot 5 \mathrm{H}_{2} \mathrm{O}\right)$, 2.5 g.; $\mathrm{NaCl}, 5.0$ g.; $\mathrm{KH}_{2} \mathrm{PO}_{4}, 1.0$ g.; $\mathrm{MgSO}_{4} .7 \mathrm{H}_{2} \mathrm{O}$, 0.1 g.; N-NaOH $5.7 \mathrm{ml}$.; water to $1 \mathrm{l}$. After autoclaving, one vol. of sterile $10 \%(\mathrm{w} / \mathrm{v})$ ammonium sulphate solution was added to 100 vols. of the basal medium.

\section{RESULTS}

When defibrinated human blood or washed red cells were incorporated in the defined medium, or added to it after growth, no haemolysis occurred, although the same conditions would give rise to haemolysis in peptone water. Enrichment of the defined medium with $\mathbf{0 . 2 5} \%$ Bacto-Peptone (Difco Laboratories Inc., Detroit) failed to produce the haemolytic phenomenon. The ingredients of the defined medium were, therefore, included separately (at usual concentration) in blood peptone water cultures. Haemolysis then occurred after overnight incubation with haemolytic strains of Bact. coli except in the medium to which sodium citrate had been added. Subsequent titration showed that, for complete inhibition of the haemolysis of one drop of defibrinated human 
blood in $8 \mathrm{ml}$. of $1 \%$ Bacto-Peptone water, a minimal concentration of $\mathbf{0 . 2} \%$ sodium citrate was required. The minimal completely inhibitory concentration of potassium oxalate was $0.03 \%$, and of sodium acetate and sodium lactate was 1-1.5\%. Partial inhibition occurred with concentrations of sodium citrate down to $0.1 \%$, potassium oxalate down to $0.008 \%$ and sodium lactate and acetate down to $0 \cdot 2 \%$. These observations suggested that calcium ions were needed for haemolysis. Even without inhibitors, the amount of calcium in the batch of $1 \%$ Bacto-Peptone water used (estimated as 0.065 $\mathrm{mg} . / 100 \mathrm{ml}$.) was below the optimum, since addition of calcium chloride $(0 \cdot 1 \%)$ enhanced the haemolysis.

A defined medium was then compounded in which Bact. coli was able to exert its haemolytic effect. A stock solution was made to contain (in $\%, w / v$ ): $\left(\mathrm{NH}_{4}\right)_{2} \mathrm{SO}_{4}, 10 ; \mathrm{KH}_{2} \mathrm{PO}_{4}, 0.5 ; \mathrm{NaCl}, 5.0 ; \mathrm{MgSO}_{4} .7 \mathrm{H}_{2} \mathrm{O}, 0.05 ;$ citric acid $\left(5 \mathrm{H}_{2} \mathrm{O}\right), 2 \cdot 0$; lactic acid (Analar), $4.0 \mathrm{v} / \mathrm{v}$. For use, $100 \mathrm{ml}$. of this solution was diluted to $c$. $900 \mathrm{ml}$, then $20 \mathrm{ml}$. of $10 \% \mathrm{CaCl}_{2} \cdot 6 \mathrm{H}_{2} \mathrm{O}$ and $60 \mathrm{ml}$. of $\mathrm{N}-\mathrm{NaOH}$ were added, the volume adjusted to 1 l., and the medium autoclaved at $120^{\circ}$ for $30 \mathrm{~min}$. When cool it was adjusted to $\mathrm{pH} 5.9$ by adding c. $13 \mathrm{ml}$. of $\mathrm{N}-\mathrm{NaOH}$, distributed, and re-autoclaved at $115^{\circ}$ for $15 \mathrm{~min}$.

In this medium, with blood or washed red cells added before or after growth, five of the haemolytic strains of Bact. coli gave good haemolysis, which was abolished when $5 \% \mathrm{MgSO}_{4} \cdot 7 \mathrm{H}_{2} \mathrm{O}$ was used instead of $10 \%$ $\mathrm{CaCl}_{2} \cdot 6 \mathrm{H}_{2} \mathrm{O}$ in making the medium. The two deficient strains (both nonmotile) haemolysed more slowly than the others under the controlled conditions described later.

An attempt to separate the haemolysin from the living bacteria was unsuccessful. Heating suspensions at $60^{\circ}$ destroyed the haemolytic power. Seitz-filtration, dialysis through cellophan, extraction of cultures with organic solvents and grinding or shaking active bacterial sediment with serum or strong peptone solution, all failed to yield demonstrable haemolysin, even in the presence of the reducing agent sodium dithionite which activates streptolysin 0 . Cultures of haemolytic strains, grown in peptone water or defined medium in collodion sacs suspended in saline containing blood, never gave haemolysis unless contamination of the outer fluid occurred.

Maximal haemolytic activity was found to occur during the logarithmic phase of growth. For studying the phenomenon, therefore, washed saline suspensions of bacterial cells were prepared (c. $10^{9}$ cells $/ \mathrm{ml}$.) from young cultures which had undergone a preliminary series of rapid cultivations. Small screw-capped bottles containing $c .4 \mathrm{ml}$. peptone water, emptied and recharged with medium twice a day for three days after primary inoculation, gave a convenient seed for rinsing into a final volume of 10 to $100 \mathrm{ml}$., which was harvested after $c .16 \mathrm{hr}$. growth. Once it was realized that the slower rate of growth on defined media compared with peptone water was due mainly to oxygen lack, there was no difficulty, using Roux bottles, in activating suspensions in these media also. By this means it was shown that calcium was necessary only for the actual haemolytic process and not for the production of the haemolytic suspension. 
The minimal haemolytic dose of such suspensions was $c .0 .025 \mathrm{ml}$. when tested against $0.5 \mathrm{ml}$. of $5 \%$ washed human red cells with $1.25 \mathrm{ml}$. saline and incubated at $37^{\circ}$ in presence of $0.02 \% \mathrm{CaCl}_{2} \cdot 6 \mathrm{H}_{2} \mathrm{O}$, the time for complete haemolysis being c. $3 \mathrm{hr}$. With twice this dose, a freshly made suspension could give complete haemolysis in $1 \mathrm{hr}$., though this, the fastest time attained, required careful preparation of a strongly haemolytic strain. In all such haemolysis tests, the tubes were inverted every half hour to resuspend the red cells.

Nothing, it therefore appeared, beyond calcium, red cells and active bacterial cells, was needed to produce the phenomenon of haemolysis. In spite of the length of time of incubation which often preceded haemolysis, the tubes when haemolysing still showed the red colour of oxyhaemoglobin, though this would become faintly mauve if left at $37^{\circ}$ overnight. When peptone was present in the tubes, reduction of haemoglobin was seen in a few hours, but was not related to the haemolysis which it succeeded or preceded according to the haemolytic activity of the bacterial suspension under test. Varying the $\mathrm{pH}$ by means of added buffers had negligible effects, provided the limits tolerated by the red cells themselves were not exceeded.

When the three essential components were varied in concentration, it was found that the ranges for producing haemolysis in $1.75 \mathrm{ml}$. total volume were: 0.005 to $2 \cdot 0 \mathrm{mg}$. calcium, $10^{6}$ to $10^{8}$ bacterial cells, and any number (optimal $5 \times 10^{8}$ to $5 \times 10^{9}$ ) of red cells. Additional calcium was not necessary in tubes containing large numbers of red cells. These figures made it appear that one bacterial cell was capable of haemolysing 5,000 red cells under the given conditions, and suggested that multiplication might occur during the test, the red cells acting as medium. The effect of adding nutrients to the haemolysis test mixtures was, therefore, investigated: Bacto-Peptone (0.1\%), or sodium citrate $(0 \cdot 1 \%)$ with and without $\left(\mathrm{NH}_{4}\right)_{2} \mathrm{SO}_{4}+\mathrm{KH}_{2} \mathrm{PO}_{4}$, decreased the time of incubation preceding haemolysis; and in their presence the advantage of a high red cell concentration was abolished.

Thus it was indirectly shown that nutriment from the red cells was activating the haemolysis test described above. This was confirmed when saline washings of red cells, tungstate (Folin-Wu) blood filtrate or serum were also found to possess activating properties, retained after boiling and filtering. Substances such as sodium citrate, which are both carbon-containing and calcium-suppressing, exert inhibitory or activating effects according to their concentration in relation to that of calcium. The process of activation was also carried out by incubation of bacterial cells with activator before adding a suspension of red cells in calcified saline, and the haemolysis time was similarly decreased. But it was noticed that the process was most effective with the least active bacterial suspensions, i.e. usually those which had aged, and that if suspensions were very fresh the effect was decreased to a minimum. It therefore seems probable that the mechanism of activation is simply that of a last-minute subculture, throwing the cells back yet again into the logarithmic phase, in the same manner as the preparatory rapid subculturing which was found necessary to improve the haemolytic power of the suspensions. 


\section{Table 1. Correlation of colony count and methylene blue reduction activity with haemolytic power of Bact. coli suspensions}

Haemolytic strain $\mathbf{7 7 7 7} / 48$ was used. Pre-incubation was carried out at $37^{\circ}$ in two 6-in. $\times \frac{3}{4}$-in. tubes in which $1 \mathrm{ml}$. of washed saline bacterial suspension $\left(10^{8}\right.$ organisms $/ \mathrm{ml}$.) was diluted $1 / 10$ in saline and in activator. Tubes of haemolysis test received $1 \mathrm{ml}$. suspension, $0.5 \mathrm{ml} .5 \%$ washed red cells, $0.05 \mathrm{ml} .1 \% \mathrm{CaCl}_{2}$ solution and $0.2 \mathrm{ml}$. saline.

\section{Time of pre-in- cubation in saline \\ (S) or activator (A) (hr.)

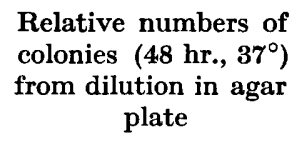
colonies $\left(48 \mathrm{hr}\right.$., $\left.37^{\circ}\right)$ from dilution in agar plate

1. Fresh suspension

$\begin{aligned} 0 & (\mathrm{~S}) \\ 0 & (\mathrm{~A}) \\ 1 & (\mathrm{~S}) \\ 1 & (\mathrm{~A}) \\ 2 & (\mathrm{~S}) \\ 2 & (\mathrm{~A}) \\ 4 & (\mathrm{~S}) \\ 4 & (\mathrm{~A}) \\ 24 & (\mathrm{~S}) \\ 24 & (\mathrm{~A})\end{aligned}$

2. Same, 24-hr. old

$$
\begin{array}{ll}
0 & (\mathrm{~S}) \\
0 & (\mathrm{~A}) \\
1 \frac{1}{2} & (\mathrm{~S}) \\
1 \frac{1}{2} & (\mathrm{~A}) \\
3 & (\mathrm{~S}) \\
3 & (\mathrm{~A})
\end{array}
$$

600
500
700
400
400
300
800
400
10,000
10,000

1-2000

1-2000

1-2000

1-2000

1-2000

1-2000

\author{
Time for \\ complete \\ lysis \\ (hr.)
}
Approx. time for re- duction of methylene blue in milk (hr.)

$\begin{array}{lc}1 \cdot 0 & 5 \cdot 5 \\ 1 \cdot 0 & 5 \cdot 5 \\ 1 \cdot 25 & 5 \cdot 5 \\ 0 \cdot 75 & 5 \cdot 5 \\ 1 \cdot 25 & 5 \cdot 5 \\ 0 \cdot 75 & 5 \cdot 5 \\ 1 \cdot 25 & 5 \cdot 5 \\ 1.25 & 5 \cdot 5 \\ 3 \cdot 00 & 7 \\ 3 \cdot 00 & 7\end{array}$

$1 \cdot 75$
$1 \cdot 5$
$2 \cdot 0$
$1 \cdot 0$
$2 \cdot 25$
$1 \cdot 25$

An example of an experiment showing the instability and re-activation of haemolytic suspensions is given in Table 1 , where, under the defined conditions given above, the haemolysis (complete) time is shown to be $1 \mathrm{hr}$. when the bacterial cells were washed and tested with a minimum of delay, and $\frac{3}{4} \mathrm{hr}$. after pre-incubation with activating solution (dilute citrate, $\mathrm{Na}_{2} \mathrm{HPO}_{4}$, $\mathrm{NH}_{4} \mathrm{Cl}$ ). Control pre-incubation in saline gave a slight lengthening of the time. Colony counts made at the same time-intervals as the successive haemolysis tests failed to show any significant change in numbers of viable bacteria due to pre-incubation in activating solution (which is not an adequate medium for growth of faecal Bact. coli) or saline, but they did show a considerable increase in numbers after 24-hr. pre-incubation, in saline as well as in activating solution, after which period the haemolysis time had lengthened to $3 \mathrm{hr}$. in both. The time taken by the suspensions to reduce methylene blue in milk was also investigated in this experiment, and found to vary rather with haemolysis time than with the increase in bacterial numbers, since at $24 \mathrm{hr}$., when the colony count had risen, the reduction time had slightly lengthened. The experiment was performed in duplicate with a non-haemolytic strain, whose results, omitted from the table, agreed with those of the haemolytic strain as regards : (1) absence of detectable increase in colony counts up to 4 $\mathrm{hr}$. but increase at $24 \mathrm{hr}$.; (2) diminished reducing activity at $24 \mathrm{hr}$. when the colony count was higher. 
The optimal haemolytic conditions of a relatively small dose of bacterial cells in the logarithmic phase, accompanied by activator, can be simply attained by centrifuging a young peptone-water culture of a haemolytic strain and adding the 'clear' supernatant to the tube of a haemolysis test (already containing calcium, saline and red cells) to give a 1/10 dilution. This finding may account for the report (Ponder \& McLachlan, 1927) of a feeble haemolysin in the supernatant of centrifuged cultures of Bact. coli.

\section{DISCUSSION}

The common property of the activating materials examined appeared to be their nutritive effect. Ammonium salts and phosphates, which increased the activating effect of sodium citrate, were inactive without the latter substance. Concentrations of $\mathrm{pH} 8.3$ borate buffer ( $>0.1 \mathrm{~m}$ in tube of test) sufficient for permanent inhibition of growth were also inhibitory to haemolysis; while lower concentrations $(c$. $0.01 \mathrm{M})$, which scarcely delayed haemolysis, were sometimes noticed later to have permitted haemoglobin reduction. But activation could not be equated with growth in the ordinary sense of an increase in the number of bacterial cells; for haemolysis was delayed when more than the optimal dose even of a highly active suspension was used; while very thick suspensions, or those made from old cultures, reduced the haemoglobin without giving more than a trace of haemolysis. The difficulty of dealing with so unstable a system as a logarithmic-phase suspension has prevented more exact definition of haemolytic conditions. These suspensions appear to continue multiplying even in saline at room temperature, and it seems that the haemolytic power is connected with one particular time phase within the process, i.e. with one passing haemolytic generation. Refrigeration at $0^{\circ}$ maintained the haemolytic power of suspensions at workable, though decreasing, levels for about three weeks. In addition to the methylene blue reduction test, other well-known metabolic actions of Bact. coli were investigated in parallel with haemolytic tests, but the generally high enzymatic activity of these haemolytic suspensions was shared by those of the non-haemolytic strains used as controls throughout this work.

\section{REFERENCES}

Dudgeon, L. S., Wordley, E. \& Bawtree, F. (1921). On Bacillus coli infection of the urinary tract, especially in relation to haemolytic organisms. J. Hyg., Camb. 20, 137.

KAYSER, H. (1903). Über Bakterienhämolysine, im Besonderen das Colilysin. Z. Hyg. InfektKr. 42, 118.

Ponder, E. \& McLachlan, D. G. S. (1927). On the kinetics of haemolysis by lysins of bacterial origin. Brit. J. exp. Path. 8, 267.

Robinson, G. L. (1932). The growth of B. pyocyaneus in synthetic media. Brit. J. exp. Path. 13, 310.

(Received 1 November 1950) 